\title{
Identification and Characterization of a Receptor for Tissue Ferritin on Activated Rat Lipocytes
}

\author{
Grant A. Ramm, Robert S. Britton, Rosemary O'Neill, and Bruce R. Bacon \\ Division of Gastroenterology and Hepatology, Department of Internal Medicine, Saint Louis University Health Sciences Center, \\ St. Louis, Missouri 63110-0250
}

\begin{abstract}
Hepatic iron overload causes lipocyte activation with resultant fibrogenesis. This study examines whether rat lipocytes express ferritin receptors, which could be involved in paracellular iron movement and in cellular regulation. Lipocytes from normal rat liver were cultured on plastic and incubated with ${ }^{125}$ I-labeled rat liver ferritin (RLF) \pm a 100 -fold excess of either unlabeled RLF or human heart ferritin, human liver ferritin, human recombinant $H$-ferritin, a mutant human recombinant $L$-ferritin, or a variety of nonspecific proteins. Specific binding sites for ferritin were demonstrated by displacement of ${ }^{125}$ I-RLF by RLF (64.5 $\left.\pm 4.3 \%\right)$ and by other ferritins (55-60\%), but not by recombinant L-ferritin. Scatchard analysis demonstrated a single class of binding sites with a $K_{d}$ of $5.1 \pm 2.9 \times 10^{-10} \mathrm{M}$, maximum binding capacity of $4.7 \pm 1.3 \times 10^{-12} \mathrm{M}$, and $5,000-10,000$ receptor sites/cell. Ferritin receptor expression was observed only in activated lipocytes. Internalization of RLF was observed within $15 \mathrm{~min}$ using FITC-RLF and confocal microscopy. This study demonstrates that $(a)$ activated lipocytes express a specific high affinity ferritin receptor; $(b)$ the binding appears to be dependent on the $H$-ferritin subunit; and (c) lipocytes internalize ferritin. Expression of ferritin receptors in activated lipocytes suggests that the receptor may either be involved in the activation cascade or may be a marker of activation. (J. Clin. Invest. 1994. 94:9-15.) Key words: Ito cell • iron - hemochromatosis • fibrosis • liver
\end{abstract}

\section{Introduction}

In hereditary hemochromatosis and in the various forms of secondary iron overload, there is a pathological increase of total body iron stores principally due to an increase in dietary iron absorption (1-3). The liver is the major recipient of this excess

Portions of this work have been presented at meetings of the American Association for the Study of Liver Diseases and have appeared in abstract form (1993. Hepatology. 18:126a) (1993. Gastroenterology. 104:977a).

Address correspondence to Bruce R. Bacon, M.D., Division of Gastroenterology and Hepatology, Department of Internal Medicine, Saint Louis University Health Sciences Center, 3635 Vista Avenue, St. Louis, MO 63110-0250.

Received for publication 20 October 1993 and in revised form 15 December 1993.

J. Clin. Invest.

(C) The American Society for Clinical Investigation, Inc. 0021-9738/94/07/0009/07 \$2.00

Volume 94, July 1994, 9-15 absorbed iron, and with severe chronic iron overload patients can develop portal fibrosis and eventually cirrhosis (1-3). Clinical evidence for iron toxicity of the liver has been provided by studies of patients with hereditary hemochromatosis, secondary iron overload due to $\beta$-thalassemia, and African iron overload (3). The precise mechanisms of iron toxicity with the subsequent development of hepatic fibrosis in conditions of iron overload are not fully understood.

The traditional role of tissue ferritin in the overall physiology of iron metabolism has been one of iron storage because of its capacity to sequester large quantities of iron in a soluble, nontoxic and biologically available form. Tissue ferritin is composed of an apoprotein shell (molecular mass $\sim 480 \mathrm{kD}$ ) which surrounds a core of up to 4,500 atoms of iron in the form of ferric hydroxy-phosphate (4). It is a globular protein made up of 24 subunits of two different subunit types, $\mathrm{H}$ or heavy $(21$ $\mathrm{kD})$ and $\mathrm{L}$ or light (19 kD) (5). A specific membrane-bound receptor for tissue ferritin has been described previously in a variety of different cells and tissues including rat and human hepatocytes, pig liver, guinea pig reticulocytes, human placenta, various tumor cell lines, and lymphocytes (6-12). The precise physiological function of the ferritin receptor is unclear, however it has been suggested that the ferritin receptor on hepatocytes acts to scavenge tissue ferritin from the circulation (13, 14). It has been proposed recently that tissue ferritin may act as an iron transport protein (15). Aisen and colleagues (15, 16) demonstrated that iron derived from Kupffer cell phagocytosis of erythrocytes is released into culture medium bound to tissue ferritin. This ferritin is subsequently internalized by the hepatocyte ferritin receptor in vitro $(15,16)$. It is not known whether this paracellular pathway functions in vivo, however it has been postulated that the hepatocellular uptake of iron from ferritin may be more physiologically relevant than previously thought (15). However, in other cell types, ferritin receptors are now postulated to be involved in cellular activation and proliferation (14). More specifically, it has been proposed that an $\mathrm{H}$-ferritin-specific receptor is expressed on lymphocytes which downregulates cellular proliferation (12).

Lipocytes (also known as Ito cells or fat-storing cells) are the hepatic cells responsible for increased collagen production in fibrogenic conditions (17). In experimental models of ironinduced hepatic fibrosis, activated lipocytes have been shown to be responsible for increased collagen production $(18,19)$. However, nothing is known about $(a)$ the mechanisms involved in lipocyte iron metabolism, $(b)$ the role of iron-binding proteins in lipocyte biology, including activation, or $(c)$ the possible involvement of these proteins in the development of ironinduced fibrogenesis. To begin to answer some of these questions, the current studies were designed to determine whether rat lipocytes express a receptor for tissue ferritin, to examine whether ferritin is internalized by lipocytes, and to determine if ferritin receptor expression is accompanied by lipocyte activation. 


\section{Methods}

Liver cell isolation and culture. Lipocytes and Kupffer cells were isolated by perfusion of normal livers from male retired breeder, SpragueDawley rats (450-550 g) (Harlan Laboratories, Indianapolis, IN) using sequential pronase and collagenase (Boehringer Mannheim Corp., Indianapolis, IN) digestion. This procedure was followed by density gradient centrifugation using arabinogalactan (Larcoll; Sigma Chemical Co., St. Louis, MO) as described previously (20). Lipocytes were harvested from the top density gradient layers of $1.04-1.045 \mathrm{~g} / \mathrm{ml}$. Lipocytes isolated in this way are vitamin A replete, demonstrating the unique characteristic of rapidly fading blue-green autofluorescence when exposed to light at a wavelength of $328 \mathrm{~nm}(21,22)$. Kupffer cells were isolated from the $1.065-1.08-\mathrm{g} / \mathrm{ml}$ interface at the bottom of the gradient. For the characterization of ferritin receptors, cells were cultured in 12-well plastic tissue culture plates (Corning Glass Works, Corning, $\mathrm{NY}$ ). Cells were maintained in an atmosphere of $5 \% \mathrm{CO}_{2} / 95 \%$ air at $37^{\circ} \mathrm{C}$ in $\mathrm{M} 199$ supplemented with $12 \mathrm{mM}$ sodium bicarbonate, $12 \mathrm{mM}$ glucose, insulin (4 U/liter), penicillin (100,000 U/liter), streptomycin $(0.1 \mathrm{~g} /$ liter $), 1 \mu \mathrm{M}$ corticosterone, and $10 \mathrm{mM}$ Hepes (termed basal medium) with $20 \%$ serum ( $10 \%$ calf $/ 10 \%$ horse). Lipocytes were also cultured in 2-well plastic chamber slides (Nunc Inc., Naperville, IL) for microscopic examination or were maintained in suspension for $4 \mathrm{~h}$ to examine the expression of ferritin receptors in quiescent cells.

The viability and purity of lipocytes at isolation were $>95$ and $>98 \%$, respectively, as assessed by trypan blue exclusion and the characteristic of rapidly fading blue-green autofluorescence, respectively. After $3 \mathrm{~d}$ of culture on uncoated plastic, the viability was $>95 \%$, and the purity was $>99 \%$. Endothelial cells and Kupffer cells did not contaminate the lipocyte cultures, as assessed by the uptake of fluorescently tagged acetoacetylated LDL (20) and the phagocytosis of 3- $\mu \mathrm{m}$ latex beads, respectively. While hepatocytes express ferritin receptors ( see Discussion), they were rarely present with $<1 \%$ contamination in 3-d lipocyte cultures. This level would not contribute significantly to the specific ferritin binding observed in cultured lipocytes. The National Research Council criteria for the care and use of laboratory animals in research were followed carefully, and the protocol was approved by the Animal Care Committee of the Saint Louis University Health Sciences Center.

Competitive binding assay. After $72 \mathrm{~h}$ in culture, the medium was replaced by basal medium containing $1 \%$ calf serum. Then, lipocytes $\left(1 \times 10^{6} /\right.$ well $)$ or Kupffer cells $\left(4 \times 10^{6} /\right.$ well $)$ were incubated for 2 $h$ at $37^{\circ} \mathrm{C}$ with $0.44 \mathrm{nM}^{125}$ I-labeled rat liver ferritin (RLF) ${ }^{1} \pm$ a 100 fold excess of either unlabeled RLF, rat transferrin (RTF), BSA, bovine $\beta$-lactoglobulin ( $\beta$-LG), human lactoferrin (HLFn), or horse spleen ferritin (HSF) (Sigma Chemical Co.). The cells were then washed three times in ice-cold Dulbecco's PBS ( $\mathrm{pH} 7.4$ ) and lysed by the addition of sodium hydroxide $(0.2 \mathrm{~N}$ final concentration). The amount of cellbound ${ }^{125}$ I-RLF was determined in the lysate using a gammacounter. Kupffer cells from the same animals were used as a negative control in this study because of the absence of membrane-bound ferritin receptors. RLF was iodinated using ${ }^{125}$ I-labeled Bolton and Hunter reagent (DuPont NEN Research Products, Boston, MA) as described previously (23). Protein concentration was determined as described previously (24).

Optimization of ${ }^{125} I-R L F$ concentration. For all subsequent experiments, only lipocytes were used and were plated at a density of 0.5 $\times 10^{6} /$ well. Cells were incubated with increasing concentrations of ${ }^{125} \mathrm{I}$ $R L F \pm a 100$-fold excess of unlabeled RLF for $2 \mathrm{~h}$ at $37^{\circ} \mathrm{C}$. Cells were then washed three times in ice-cold PBS, and cell-bound ${ }^{125}$ I-RLF was determined as described above.

1. Abbreviations used in this paper: $B_{\max }$, maximum binding capacity; HHF, human heart ferritin; HLF, human liver ferritin; HLFn, human lactoferrin; HrHF, human recombinant $\mathrm{H}$-ferritin; HrLF, human recombinant L-ferritin; HSF, horse spleen ferritin; $\beta$-LG, $\beta$-lactoglubulin; RLF, rat liver ferritin; RTF, rat transferrin.
Time course study. Lipocytes were incubated at $37^{\circ} \mathrm{C}$ with $0.67 \mathrm{nM}$ ${ }^{125} \mathrm{I}-\mathrm{RLF} \pm \mathrm{a} 100$-fold excess of unlabeled RLF for up to $150 \mathrm{~min}$. At each time point, the cells were processed for determination of cellbound ${ }^{125}$ I-RLF as described above.

Ferritin subunit specificity. To determine the ferritin subunit specificity of the ferritin receptor, lipocytes were incubated for $2 \mathrm{~h}$ at $37^{\circ} \mathrm{C}$ with $0.67 \mathrm{nM}{ }^{125} \mathrm{I}-\mathrm{RLF} \pm \mathrm{a} 100$-fold excess of either unlabeled RLF, human heart ferritin (HHF), human liver ferritin (HLF) (Scripps Laboratories, San Diego, CA), human recombinant $\mathrm{H}$-ferritin (HrHF), or human recombinant L-ferritin (HrLF) (S6T-K86Q, kindly provided by Dr. Paolo Arosio, University of Milano, Italy). The HrLF mutant contains two amino acid substitutions, which do not affect the biochemical and functional properties of the ferritin (Dr. Paolo Arosio, personal communication). Cell-bound ${ }^{125}$ I-RLF was determined as described above.

Scatchard analysis. In separate experiments, lipocytes were incubated with $0.67 \mathrm{nM}{ }^{125} \mathrm{I}-\mathrm{RLF}$ for $2 \mathrm{~h}$ at $37^{\circ} \mathrm{C} \pm$ increasing concentrations of unlabeled RLF ranging from $1.1 \times 10^{-11}$ to $3.3 \times 10^{-7} \mathrm{M}$. Cellbound ${ }^{125}$ I-RLF was determined as described above. Scatchard analysis was performed on the binding data using the "LIGAND" computer program as described previously (25).

Internalization of FITC-labeled RLF. FITC-labeled RLF (specifically prepared for these experiments by Molecular Probes, Inc., Eugene, OR) was added to lipocytes grown on plastic chamber slides, at a final concentration of $0.19 \mu \mathrm{M}$ RLF. After a 15 -min incubation at $37^{\circ} \mathrm{C}$, the wells were washed twice with Krebs' buffer ( $\mathrm{pH} 7.4)$, and then $1 \mathrm{ml}$ of Krebs' buffer $\left(37^{\circ} \mathrm{C}\right)$ was placed in each well. The cells were examined for the subcellular presence of FITC-labeled RLF over a 45-min period, using a confocal-laser microscope (ACAS 570; Meridian Instruments, Inc., Okemos, MI). This instrument was equipped with a 5-W argon laser and used a computerized stage for X-Y movements. The excitation wavelength used in the detection of internalized FITC-labeled RLF was $488 \mathrm{~nm}$ (with laser power set at $100 \mathrm{~mW}$ ), and the fluorescence (emission) was measured using a 530-nm FITC filter. Confocal images were captured using a computer-enhanced pseudocolor scale. Images of background lipocyte autofluorescence were captured before the addition of FITC-labeled RLF to verify that this phenomenon did not interfere with the detection of the FITC-labeled RLF signal.

Demonstration of lipocyte activation. When lipocytes are cultured on uncoated plastic in a medium containing serum, they proliferate and ultimately develop a "myofibroblast-like" phenotype (26). One of the markers of this activation process is $\alpha$-smooth muscle actin (27). Activation of lipocytes was determined in both freshly isolated cells and in cells cultured for $3 \mathrm{~d}$ in chamber slides by detecting the expression of $\alpha$ smooth muscle actin using the following methods. For immunostaining, lipocytes were washed in PBS and fixed with ice-cold methanol for 5 min. Nonspecific binding was blocked as described previously (27). Lipocytes were incubated overnight $\left(25^{\circ} \mathrm{C}\right)$ with mouse anti- $\alpha$-smooth muscle actin antibody (1:400, clone 1A4; Sigma Chemical Co.). Then, the cells were washed and incubated for $2 \mathrm{~h}\left(25^{\circ} \mathrm{C}\right)$ with anti-mouse IgG antibody conjugated to FITC. After washing, lipocytes were examined by fluorescence microscopy for the characteristic fibrillar appearance of immunofluorescent $\alpha$-smooth muscle actin filaments (27). For Western blot analysis, cells were solubilized with SDS-lysis buffer and sonicated for $20 \mathrm{~s}$. Then, the cell lysate was boiled for $3 \mathrm{~min}$, and the suspension was centrifuged at $16,000 \mathrm{~g}$ for $20 \mathrm{~min}\left(4^{\circ} \mathrm{C}\right)$. The supernatant was subjected to SDS-PAGE, followed by Western blotting as described previously (27). The membranes were incubated sequentially with mouse anti- $\alpha$-smooth muscle actin antibody and horseradish peroxidase-conjugated anti-mouse IgG antibody and, finally, chemiluminescence detection (ECL; Amersham Corp., Arlington Heights, IL) was performed.

Suspension assay. Ferritin receptor expression was also examined in quiescent cells. Lipocytes were maintained in suspension (in a shaking waterbath) at $37^{\circ} \mathrm{C}$ in an atmosphere of $5 \% \mathrm{CO}_{2} / 95 \% \mathrm{O}_{2}$, in basal medium containing $20 \%$ serum for $4 \mathrm{~h}$. Viability of lipocytes was maintained at $>90 \%$ during this time. Quiescence was confirmed by the absence of $\alpha$-smooth muscle actin expression determined by both immu- 

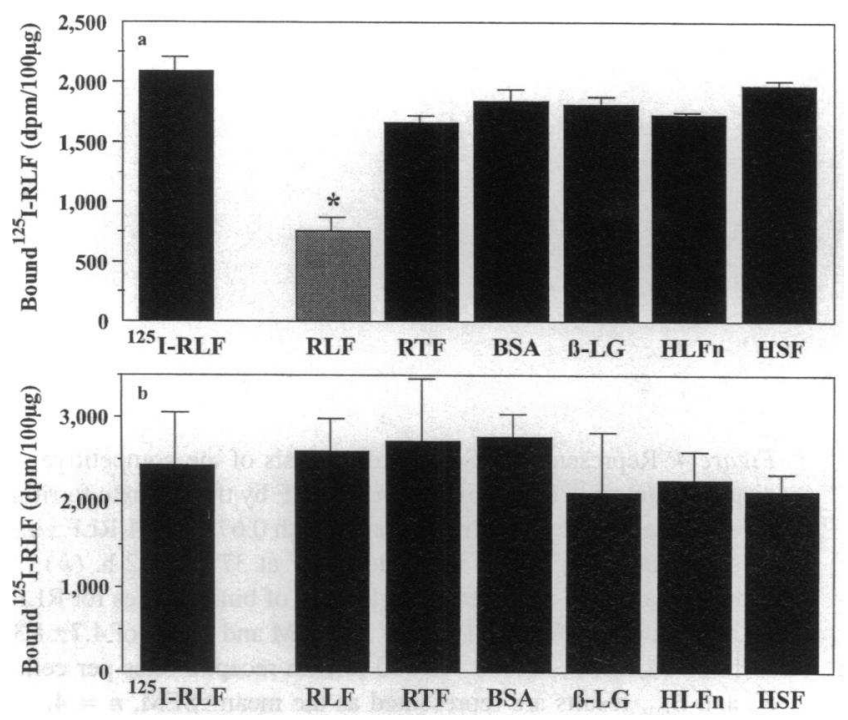

Figure 1. Identification of the lipocyte ferritin receptor. (a) Lipocytes or $(b)$ Kupffer cells isolated from the same rat liver were incubated with $0.44 \mathrm{nM}{ }^{125} \mathrm{I}-\mathrm{RLF} \pm \mathrm{a} 100$-fold excess of either unlabeled RLF, RTF, BSA, $\beta$-LG, HLFn, or HSF at $37^{\circ} \mathrm{C}$ for $2 \mathrm{~h}$. Lipocytes demonstrated $64.5 \pm 4.3 \%$ specific binding for RLF only. Kupffer cells showed no specific binding of RLF. Mean \pm SEM, $n=3$. $* P<0.001$.

nostaining and Western blotting. After $4 \mathrm{~h}$, the cells were centrifuged and resuspended in basal medium containing $1 \%$ calf serum. Lipocytes were aliquoted $\left(0.5 \times 10^{6}\right.$ cells $\left./ \mathrm{ml}\right)$ into tubes containing $0.67 \mathrm{nM}^{125} \mathrm{I}$ $R L F \pm a 100$-fold excess of unlabeled RLF and incubated at $37^{\circ} \mathrm{C}$. After $2 \mathrm{~h}$, the cells were washed in $3 \mathrm{ml}$ ice-cold PBS, and the cell pellet was lysed with sodium hydroxide $(0.2 \mathrm{~N})$ and counted for lipocytebound ${ }^{125}$ I-RLF.

Ferritin receptor expression could not be determined on lipocytes maintained in a quiescent phenotype by culture on the extracellular growth matrix Matrigel (Becton Dickinson Labware, Bedford, MA) because of the high level of nonspecific binding of ${ }^{125} \mathrm{I}-\mathrm{RLF}$ by Matrigel.

Presentation of data and statistical analysis. Results are represented as the mean \pm SEM of triplicate wells with at least three independent cell preparations in each group. The binding results are expressed as disintegrations per minute per microgram of protein. The level of cellspecific binding was determined by subtracting the nonspecific binding (i.e., in the presence of a 100 -fold excess of unlabeled protein competitor) from the total ${ }^{125}$ I-RLF bound by the cells. The statistical significance between groups was assessed using the Student's $t$ test.

\section{Results}

Competitive binding assay. Ferritin receptor binding was identified on rat lipocytes by the competitive displacement of ${ }^{125} \mathrm{I}$ RLF by a 100 -fold excess of unlabeled RLF only (Fig. $1 a$ ). The level of specific binding of ${ }^{125} \mathrm{I}-\mathrm{RLF}$ to lipocytes was $64.5 \pm 4.3 \%$ in this experiment. There was no competitive displacement of ${ }^{125}$ I-RLF by either RTF, BSA, $\beta$-LG, HLFn, or HSF. Rat Kupffer cells did not demonstrate specific binding of ${ }^{125} \mathrm{I}-\mathrm{RLF}$ (Fig. $1 \mathrm{~b}$ ).

Optimization of ${ }^{125}$ I-RLF concentration and time course study. When lipocytes were incubated with increasing concentrations of ${ }^{125}$ I-RLF for $120 \mathrm{~min}$, there was an increase in the amount of ${ }^{125} \mathrm{I}-\mathrm{RLF}$ binding by the cells. The level of specific binding increased to $65.4 \pm 5.6 \%$ when the concentration of ${ }^{125} \mathrm{I}$ -
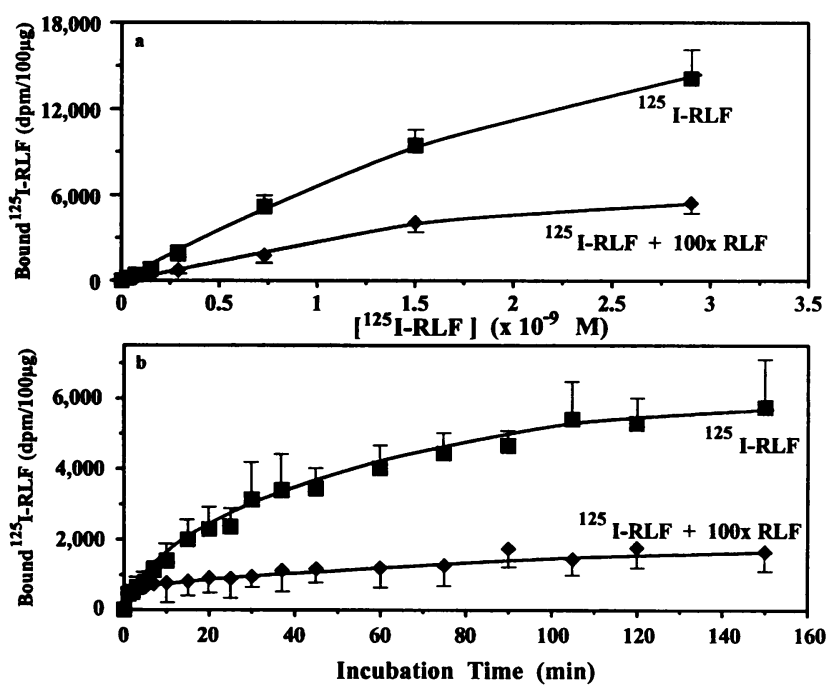

Figure 2. (a) Optimization of ${ }^{125} \mathrm{I}-\mathrm{RLF}$ concentration. Lipocytes were incubated with increasing concentrations of ${ }^{125} \mathrm{I}-\mathrm{RLF} \pm \mathrm{a} 100$-fold excess of unlabeled RLF at $37^{\circ} \mathrm{C}$ for $2 \mathrm{~h}$. The amount of ${ }^{125} \mathrm{I}-\mathrm{RLF}$ binding increased with increasing concentrations of ${ }^{125} \mathrm{I}$-RLF. Maximal specific binding of ${ }^{125} \mathrm{I}-\mathrm{RLF}(65.4 \pm 5.6 \%)$ was obtained using $0.67 \mathrm{nM}{ }^{125} \mathrm{I}-\mathrm{RLF}$. Mean \pm SEM, $n=3$. ( $b$ ) Time course of ${ }^{125}$ I-RLF binding by lipocytes. Lipocytes were incubated with $0.67 \mathrm{nM}^{125} \mathrm{I}-\mathrm{RLF} \pm \mathrm{a} 100$-fold excess of unlabeled $\mathrm{RLF}$ at $37^{\circ} \mathrm{C}$ for up to $150 \mathrm{~min}$. Binding reached saturation after $\sim 120$ min. Mean \pm SEM,

$n=3$.

RLF was $0.67 \mathrm{nM}$ (Fig. $2 a$ ). There was no further increase in the percentage of specific binding at higher concentrations, and $0.67 \mathrm{nM}^{125} \mathrm{I}-\mathrm{RLF}$ was used in all further studies of the characterization of the ferritin receptor. The specific binding of $0.67 \mathrm{nM}$ ${ }^{125}$ I-RLF to lipocytes reached saturation after incubation for 120 $\min$ (Fig. $2 b$ ).

Ferritin subunit specificity. Fig. 3 demonstrates the results of a study designed to examine the ferritin subunit specificity of the lipocyte ferritin receptor. HrHF, HLF, and HHF all demonstrated competitive displacement of ${ }^{125} \mathrm{I}-\mathrm{RLF}$ with $56 \pm 2$, $55 \pm 6$, and $60 \pm 6 \%$ specific binding, respectively. HrLF, however, showed no competitive displacement of ${ }^{125}$ I-RLF.

Scatchard analysis. Scatchard analysis of the competitive dis-

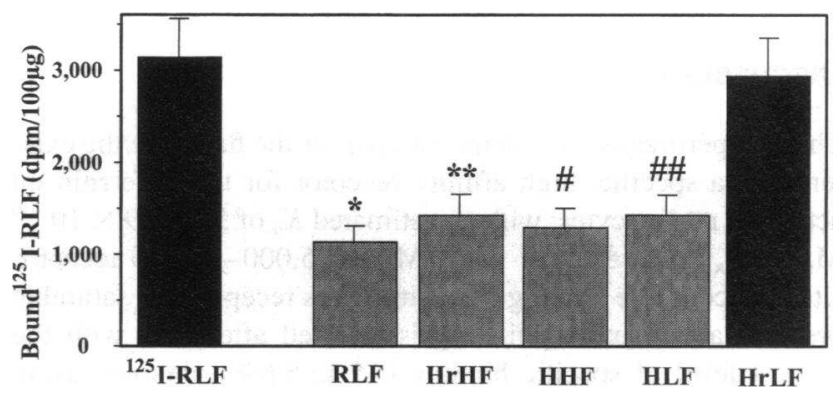

Figure 3. Ferritin subunit specificity of the lipocyte ferritin receptor. Lipocytes were incubated with $0.67 \mathrm{nM}{ }^{125} \mathrm{I}-\mathrm{RLF} \pm \mathrm{a} 100$-fold excess of either unlabeled RLF, HHF, HLF, HrHF, or a mutant isoform of HrLF at $37^{\circ} \mathrm{C}$ for $2 \mathrm{~h}$. Competitive displacement of ${ }^{125} \mathrm{I}-\mathrm{RLF}$ was demonstrated by RLF $(64.5 \pm 4.3 \%)$, HHF $(60 \pm 6 \%)$, HLF $(55 \pm 6 \%)$, and HrHF $(56 \pm 2 \%$ ), but not by the mutant isoform of HrLF. Mean \pm SEM, $n=3$. ${ }^{*} P<0.001, * * P<0.01,{ }^{*}$ and ${ }^{* *} P<0.005$. 

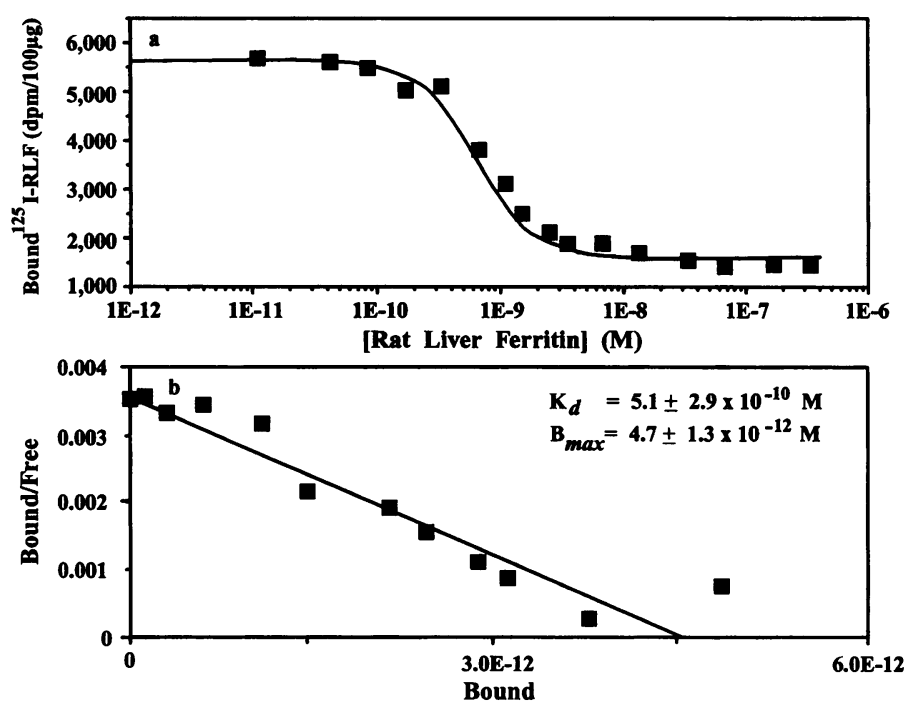

Figure 4. Representative Scatchard analysis of the competitive displacement of ${ }^{125} \mathrm{I}-\mathrm{RLF}$ by unlabeled RLF by the lipocyte ferritin receptor. (a) Lipocytes were incubated with $0.67 \mathrm{nM}^{125 \mathrm{I}-\mathrm{RLF} \pm \mathrm{in}-}$ creasing concentrations of unlabeled RLF at $37^{\circ} \mathrm{C}$ for $2 \mathrm{~h} .(b)$ Scatchard analysis indicated a single class of binding sites for RLF with an estimated $K_{\mathrm{d}}$ of $5.1 \pm 2.9 \times 10^{-10} \mathrm{M}$ and a $B_{\max }$ of $4.7 \pm 1.3$ $\times 10^{-12} \mathrm{M}$, with $\sim 5,000-10,000$ ferritin receptor sites per cell. $K_{\mathrm{d}}$ and $B_{\max }$ results are represented as the mean \pm SEM, $n=4$. placement of ${ }^{125}$ I-RLF by unlabeled RLF (Fig. $4 a$ ) suggested a single class of binding sites for RLF was present on rat lipocytes, with an estimated $K_{\mathrm{d}}$ of $5.1 \pm 2.9 \times 10^{-10} \mathrm{M}$ and a maximum binding capacity $\left(B_{\max }\right)$ of $4.7 \pm 1.3 \times 10^{-12} \mathrm{M}$ (Fig. $4 \mathrm{~b}$ ). Rat lipocytes express $\sim 5,000-10,000$ ferritin receptor sites per cell.

Internalization of FITC-labeled RLF. Lipocytes cultured on plastic chamber slides were examined using fluorescence confocal microscopy both before (Fig. $5 a$ ) and after the addition of FITClabeled RLF (Fig. 5 b). Internalization of RLF was observed within $15 \mathrm{~min}$. Fig. $5 \mathrm{~b}$ demonstrates the internalization of FITClabeled RLF 45 min after initial incubation, with FITC-labeled RLF observed inside the lipocyte cell membrane but excluded from the nucleus.

Coordinate expression of $\alpha$-smooth muscle actin and ferritin receptors. After $3 \mathrm{~d}$, lipocytes grown on uncoated plastic tissue culture dishes expressed both $\alpha$-smooth muscle actin (Fig. 6, $a$ and $b$ ) and ferritin receptors (Fig. $6 c$ ). The expression of $\alpha$ smooth muscle actin was demonstrated using both immunohistochemical (Fig. $6 a$ ) and Western blotting techniques (Fig. $6 b$ ). These findings verify that all experiments designed to identify and characterize the expression of ferritin receptors were conducted on activated lipocytes. Freshly isolated lipocytes did not express $\alpha$ smooth muscle actin, indicating that these cells were quiescent. Quiescent lipocytes did not express ferritin receptors (Fig. $6 c$ ).

\section{Discussion}

These experiments have demonstrated for the first time the existence of a specific, high affinity receptor for tissue ferritin on activated rat lipocytes, with an estimated $K_{\mathrm{d}}$ of $5.1 \pm 2.9 \times 10^{-10}$ $\mathrm{M}$, a $B_{\max }$ of $4.7 \pm 1.3 \times 10^{-12} \mathrm{M}$, and 5,000-10,000 receptor sites per cell. The binding of ferritin to its receptor is a saturable process, and maximal binding is reached after $2 \mathrm{~h}$, with the highest level of specific binding $(65.4 \pm 5.6 \%)$ obtained using $0.67 \mathrm{nM}^{125} \mathrm{I}-\mathrm{RLF}$. We have also shown that the receptor appears to behave as a "scavenger" for tissue ferritin and that the binding of ferritin to the lipocyte ferritin receptor appears to be dependent on the H-ferritin subunit. Finally, we have demonstrated that tissue ferritin is internalized by rat lipocytes and that the ferritin receptor is expressed in activated but not in quiescent lipocytes.
Until recently, very little was known about the cells responsible for the increased production of extracellular matrix observed in fibrogenic conditions. With current advances in hepatic cell separation, activated lipocytes have been demonstrated to be the principal collagen-producing cells in hepatic fibrogenesis $(17-19,28,29)$. Morphological studies in both humans and in experimental animals have shown that in hepatic fibrogenesis, lipocytes become activated, taking on a myofibroblast-like phenotype $(17,26,27,29)$. This process involves increased proliferation $(26,30)$, decreased cellular vitamin A stores $(26,27,31)$, increased expression of the genes responsible for extracellular matrix production (28), and the expression of $\alpha$-smooth muscle actin $(27,32)$. Activated lipocytes have been shown to be responsible for the increased collagen production observed in various experimental models of hepatic fibrosis (28), including iron overload $(18,19)$, perhaps due to products of lipid peroxidation (33). In this study, lipocyte activation, as evidenced by the expression of $\alpha$-smooth muscle actin, was accompanied by the expression of ferritin receptors. Whether ferritin receptor expression is involved in initiating the activation process or is a marker of activation remains to be elucidated.

While there are no previous data on lipocyte ferritin receptors, the existence of ferritin receptors on hepatocytes (6-8, 13) and on several other cell types and tissues (14) is well documented, with similar binding affinities as those observed in this study. Rat hepatocytes have been shown to express a ferritin receptor with a $K_{\mathrm{d}}$ of $1 \times 10^{-9} \mathrm{M}, 30,000$ binding sites per cell, and specific binding of $\sim 50-60 \%$ (6). Other studies using human and pig hepatocytes $(7,8)$, guinea pig reticulocytes (9), and immature red blood cells (34) have observed specific ferritin binding with $K_{\mathrm{d}}$ values ranging from $1.7 \times 10^{-9}$ to $3.4 \times 10^{-10} \mathrm{M}(35)$. Human MOLT-4 $\mathrm{T}$ lymphoid cells demonstrate specific binding for HrHF with a $K_{\mathrm{d}}$ of $1.4 \times 10^{-8}$ $M$ and $\sim 6,000-15,000$ receptor sites per cell (35).

It is generally accepted that most cells acquire iron through either receptor- or nonreceptor-mediated uptake of transferrinbound iron (36). Recent studies have suggested that tissue ferritin may act as an iron transport protein in the paracellular movement of iron from Kupffer cells to hepatocytes $(15,37)$. Aisen and colleagues (15) have postulated that hepatocytes may ac- 

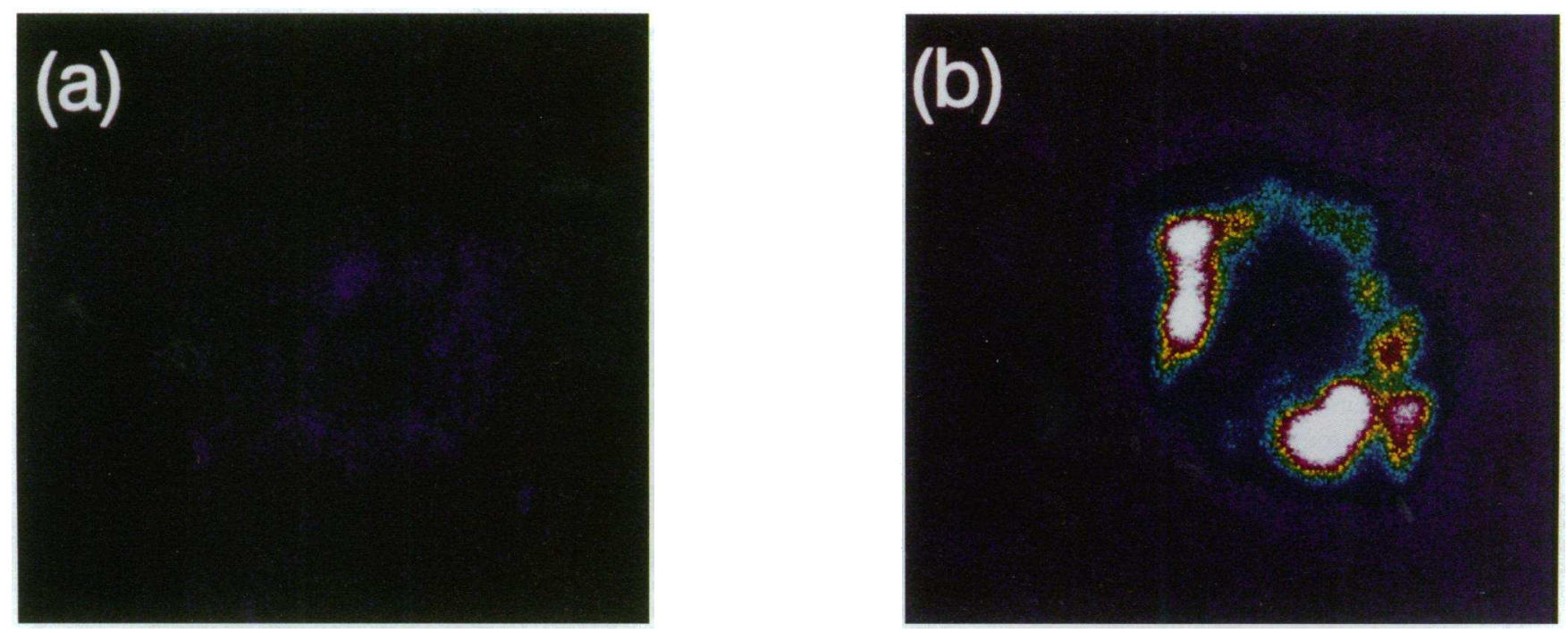

Figure 5. Representative image of five independent lipocyte preparations, showing the internalization of FITC-labeled RLF by lipocytes. Lipocytes on chamber slides were incubated with FITC-labeled RLF (at a final concentration of $0.19 \mu \mathrm{M}$ RLF) for 15 min and then were washed in Krebs' buffer. After a further $30 \mathrm{~min}$, FITC-labeled RLF was observed inside the lipocyte cell membrane, with a clearly defined nucleus which excluded FITC-labeled RLF. Panel $(a)$ demonstrates a lipocyte with background fluorescence before the addition of FITC-labeled RLF. Panel $(b)$ shows internalization of FITC-labeled RLF.
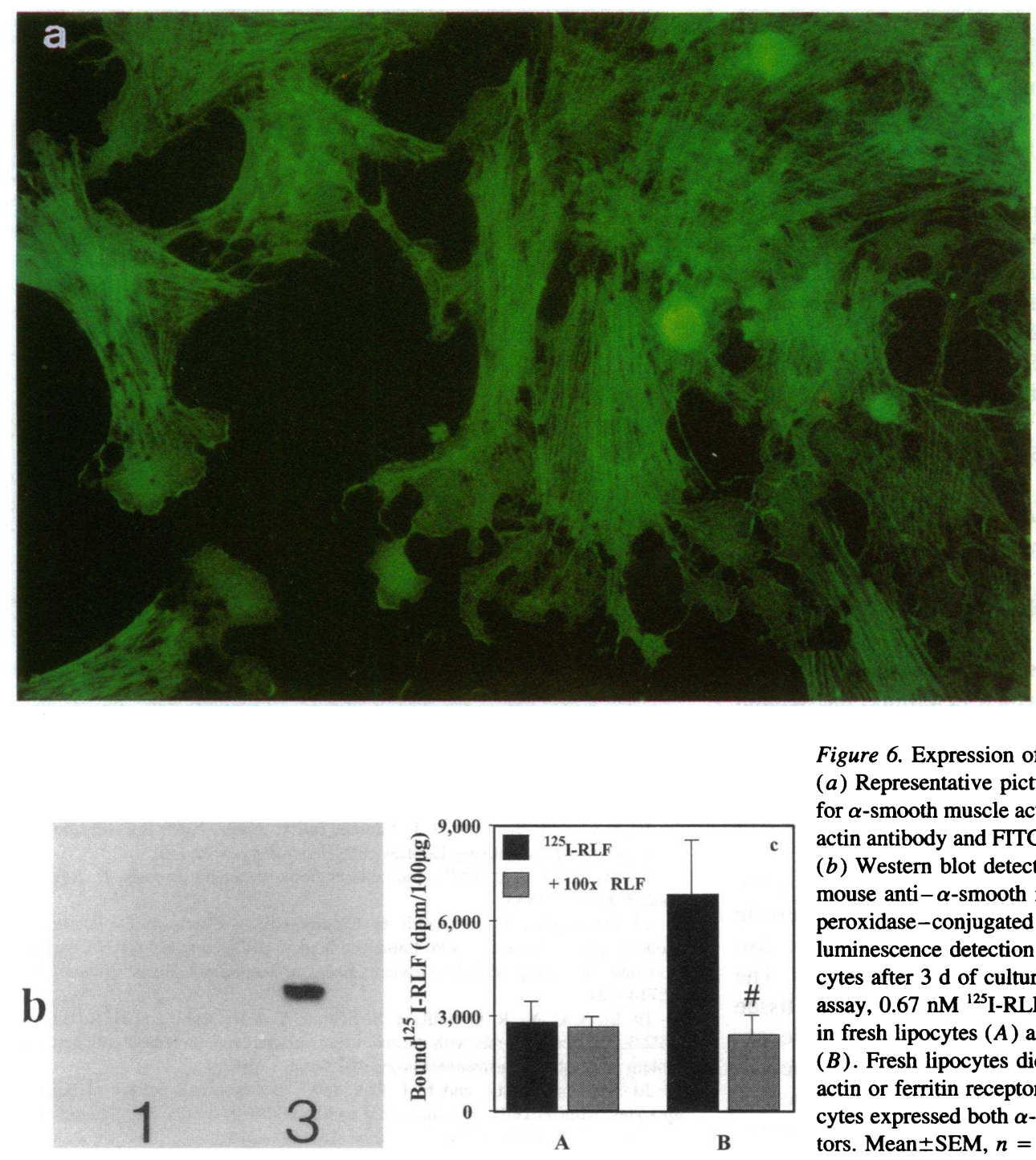

Figure 6. Expression of $\alpha$-smooth muscle actin in lipocytes. (a) Representative picture of immunohistochemical staining for $\alpha$-smooth muscle actin using mouse anti- $\alpha$-smooth muscle actin antibody and FITC-labeled anti-mouse IgG antibody and (b) Western blot detection for $\alpha$-smooth muscle actin using mouse anti- $\alpha$-smooth muscle actin antibody and horseradish peroxidase-conjugated anti-mouse IgG antibody with chemiluminescence detection (lane 1 , fresh lipocytes; lane 3 , lipocytes after $3 \mathrm{~d}$ of culture on plastic). (c) Competitive binding assay, $0.67 \mathrm{nM}{ }^{125} \mathrm{I}-\mathrm{RLF} \pm \mathrm{a} 100$-fold excess of unlabeled RLF in fresh lipocytes $(A)$ and lipocytes cultured on plastic for $3 \mathrm{~d}$ $(B)$. Fresh lipocytes did not express either $\alpha$-smooth muscle actin or ferritin receptors. After $3 \mathrm{~d}$ of culture on plastic, lipocytes expressed both $\alpha$-smooth muscle actin and ferritin receptors. Mean \pm SEM, $n=3$. $^{*} P<0.005$. 
quire up to $1.2 \times 10^{6}$ atoms of iron per cell per minute through the internalization of ferritin by the hepatocyte ferritin receptor. The comparative level of iron acquisition from transferrin was estimated at $4 \times 10^{6}$ atoms of iron per cell per minute (15). This iron transport pathway could potentially represent a significant route of iron flux into the hepatocyte. With the demonstration of a lipocyte ferritin receptor and the potential for a paracellular pathway of iron transport between liver cells, it is possible that a similar route of iron flux from Kupffer cells to lipocytes may exist. Suggestive evidence for the existence of such a pathway may come from a recent study which examined iron-induced hepatic fibrosis in the gerbil (38). A single parenteral injection of iron-dextran was administered to gerbils and resulted in the deposition of iron predominantly in the Kupffer cells. After 6 wk, increased hepatic fibrosis was present, and at 3 mo micronodular cirrhosis was observed. Ferritin was observed within hepatic lipocytes, however it was not clear whether this ferritin was synthesized endogenously or whether it was taken up after the parenteral iron loading of Kupffer cells. Findings from our present study provide a possible explanation for the observations in gerbils. Since we have demonstrated that tissue ferritin is internalized by lipocytes in vitro, it is possible to speculate that a Kupffer cell to lipocyte paracellular iron/ferritin pathway may exist.

In addition to a possible role in mediating paracellular ferritin movement, the lipocyte ferritin receptor may modulate lipocyte activation and/or proliferation, as described in other cell types $(14,39)$. Several groups have demonstrated that ferritin inhibits the proliferation of granulocyte-macrophage and erythroid progenitor cells (40-42). Recent studies have shown that $\mathrm{H}$-ferritin receptors on proliferating lymphocytes (12) and erythroid cells (43) probably mediate H-ferritin-induced growth suppression. These investigators have shown that $\mathrm{H}$ ferritin-binding sites are a marker for lymphocyte proliferation, with the specific function of downregulating proliferation. More recent evidence suggests that the ferroxidase site on $\mathrm{H}$-ferritin subunits is necessary for this growth suppression activity (44). The H-ferritin-dependent binding of RLF (which contains on average $37-43 \% \mathrm{H}$ subunits $)(45,46)$ to activated lipocytes is supported by the observations that HHF (which contains predominantly $\mathrm{H}$ subunits) (47) and HrHF inhibit RLF binding, while HrLF and HSF (which contains predominantly $L$ subunits ) $(47,48)$ do not affect RLF binding. HLF also inhibited the binding of RLF to lipocytes. HLF contains $\sim 10 \% \mathrm{H}$ subunits (47), which may explain this observation. Further investigation will be required to fully elucidate the structural differences between $\mathrm{H}$ - and L-ferritin which determine the subunit specificity of the lipocyte ferritin receptor. Since ferritin receptor activity is present in activated but not in quiescent lipocytes, it is possible that the ferritin receptor is either involved in the activation cascade or that the expression of the ferritin receptor is a marker of lipocyte activation.

In summary, we have demonstrated for the first time the existence of a specific, high affinity receptor for tissue ferritin on activated, but not on quiescent, rat lipocytes. We have also shown that ferritin is internalized by activated lipocytes. The lipocyte ferritin receptor appears to act as a scavenger for tissue ferritin, and the binding of ferritin to the receptor may be dependent on the $\mathrm{H}$ subunit. Ferritin receptors therefore have potential roles in lipocyte iron metabolism and in modulating the activation state and/or proliferation of lipocytes in hepatic fibrogenesis.

\section{Acknowledgments}

The human recombinant $\mathrm{H}$ - and $\mathrm{L}$-ferritins were generous gifts from Dr. Paolo Arosio, University of Milano, Italy. The authors wish to thank Dr. Bruce Luxon and Michael Milliano for their assistance with the image analysis of the internalized FITC-labeled RLF; Dr. Ron Worthington (Monsanto Corporation, St. Louis, MO) for the use of the confocal microscope; and Dr. Anne Andorn for her guidance in the use of the LIGAND program.

This study was supported by a grant from the U. S. Public Health Service (R01 DK-41816). Dr. Ramm was supported in part by a PostDoctoral Research Fellowship from the American Liver Foundation (Dean Thiel Foundation Award).

\section{References}

1. Powell, L. W., L. Jazwinska, and J. W. Halliday. 1994. Primary iron overload. In Iron Metabolism in Health and Disease. J. H. Brock, J. W. Halliday, M. J. Pippard, and L. W. Powell, editors. W. B. Saunders Co., London. 227-270.

2. Nichols, G. M., and B. R. Bacon. 1989. Hereditary hemochromatosis: pathogenesis and clinical features of a common disease. Am. J. Gastroenterol. 84:851-862.

3. Tavill, A. S., and B. R. Bacon. 1990. Hemochromatosis: iron metabolism and the iron overload syndromes. In Hepatology: A Textbook of Liver Disease. D. Zakim and T. D. Boyer, editors. W. B. Saunders Co., Philadelphia. 12731299.

4. Harrison, P. M., G. A. Clegg, and K. May. 1980. Ferritin structure and function. In Iron in Biochemistry and Medicine II. A. Jacobs and M. Worwood, editors. Academic Press, London. 131-171.

5. Theil, E. C. 1987. Ferritin: structure, gene regulation and cellular function in animals, plants and microorganisms. Annu. Rev. Biochem. 56:289-315.

6. Mack, U., L. W. Powell, and J. W. Halliday. 1983. Detection and isolation of a hepatic membrane receptor for ferritin. J. Biol. Chem. 258:4672-4675.

7. Adams, P. C., L. W. Powell, and J. W. Halliday. 1988. Isolation of a human hepatic ferritin receptor. Hepatology. 9:719-721.

8. Adams, P. C., U. Mack, L. W. Powell, and J. W. Halliday. 1988. Isolation of a porcine hepatic ferritin receptor. Comp. Biochem. Physiol. B. 90:837-841.

9. Blight, G. D., and E. H. Morgan. 1987. Receptor-mediated endocytosis of transferrin and ferritin by guinea-pig reticulocytes. Uptake by a common endocytic pathway. Eur. J. Cell Biol. 43:260-265.

10. Takami, M., K. Mizumoto, I. Kasuya, K. Kino, H. H. Sussman, and H. Tsunoo. 1986. Human placental ferritin receptor. Biochim. Biophys. Acta. 884:3138.

11. Anderson, G. J., W. P. Faulk, P. Arosio, D. Moss, L. W. Powell, and J. W. Halliday. 1989. Identification of H- and L-ferritin subunit binding sites on human T and B lymphoid cells. Br. J. Haematol. 73:260-264.

12. Fargion, S., A. L. Fracanzani, B. Brando, P. Arosio, S. Levi, and G. Fiorelli. 1991. Specific binding sites for H-ferritin on human lymphocytes: modulation during cellular proliferation and potential implication in cell growth control. Blood. 78:1056-1061.

13. Mack, U., E. L. Storey, L. W. Powell, and J. W. Halliday. 1982. Characterization of the binding of ferritin to the rat hepatic ferritin receptor. In Proteins of Iron Storage and Transport. G. Spik, J. Montreuil, R. R. Crichton, and J. Mazurier, editors. Elsevier, Amsterdam. 203-206.

14. Moss, D., S. Fargion, A. L. Fracanzani, S. Levi, M. D. Cappellini, P. Arosio, L. W. Powell, and J. W. Halliday. 1992. Functional roles of the ferritin receptors of human liver, hepatoma, lymphoid and erythroid cells. J. Inorg. Biochem. 47:219-227.

15. Sibille, J.-C., H. Kondo, and P. Aisen. 1988. Interactions between isolated hepatocytes and Kupffer cells in iron metabolism: a possible role for ferritin as an iron carrier protein. Hepatology. 8:296-301.

16. Kondo, H., K. Saito, J. P. Grasso, and P. Aisen. 1988. Iron metabolism in the erythrophagocytosing Kupffer cell. Hepatology. 8:32-38.

17. Friedman, S. L. 1993. The cellular basis of hepatic fibrosis. N. Engl. J. Med. 328:1828-1835.

18. Pietrangelo, A., R. Gualdi, G. Casalgrandi, A. Geerts, P. De Bleser, G. Montosi, and E. Ventura. 1994. Enhanced hepatic collagen type I mRNA expression into fat-storing cells in a rodent model of hemochromatosis. Hepatology. 19:714-721.

19. Li, S. C. Y., R. O'Neill, R. S. Britton, Y. Kobayashi, and B. R. Bacon. 1992. Lipocytes from rats with chronic iron overload have increased collagen and protein production. Gastroenterology. 102:841a. (Abstr.)

20. Friedman, S. L., and F. J. Roll. 1987. Isolation and culture of hepatic lipocytes, Kupffer cells, and sinusoidal endothelial cells by density gradient centrifugation with Stractan. Anal. Biochem. 161:207-218.

21. Wake, K. 1980. Perisinusoidal stellate cells (fat-storing cells, interstitial 
cells, lipocytes), their related structure in and around the liver sinusoids, and vitamin A-storing cells in extrahepatic organs. Int. Rev. Cytol. 66:303-353.

22. Maher, J. J., D. M. Bissell, S. L. Friedman, and F. J. Roll. 1988. Collagen measured in primary cultures of normal rat hepatocytes derives from lipocytes within the monolayer. J. Clin. Invest. 82:450-459.

23. Bolton, A. E., and W. M. Hunter. 1973. The labelling of proteins to high specific radioactivities by conjugation to a ${ }^{125} \mathrm{I}$-containing acylating agent. Biochem. J. 133:529-539.

24. Lowry, O. H., N. J. Rosebrough, A. L. Farr, and R. J. Randall. 1951. Protein measurement with the Folin phenol reagent. J. Biol. Chem. 193:265-275.

25. Munson, P. J., and D. Rodbard. 1980. LIGAND: a versatile computerized approach for characterization of ligand-binding systems. Anal. Biochem. 107:220239.

26. DeLeeuw, A. M., S. P. McCarthy, A. Geerts, and D. L. Knook. 1984 Purified rat liver fat storing cells divide in culture and contain collagen. Hepatology. 4:392-403.

27. Rockey, D. C., J. K. Boyles, G. Gabbiani, and S. L. Friedman. 1992. Rat hepatic lipocytes express smooth muscle actin upon activation in vivo and in culture. J. Submicrosc. Cytol. Pathol. 24:193-203.

28. Maher, J. J., and R. F. McGuire. 1990. Extracellular matrix gene expression increases preferentially in rat lipocytes and sinusoidal endothelial cells during hepatic fibrosis in vivo. J. Clin. Invest. 86:1641-1648.

29. Martinez-Hernandez, A. 1985. The hepatic extracellular matrix. II. Electron immunohistochemical studies in rats with $\mathrm{CCl}_{4}$-induced cirrhosis. Lab. Invest. 53:166-186.

30. Geerts, A., J. M. Lazou, P. De Bleser, and E. Wisse. 1991. Tissue distribution, quantitation and proliferation kinetics of fat-storing cells in carbon tetrachloride-injured rat liver. Hepatology. 13:1193-1202.

31. Takahara, T., T. Kojima, C. Miyabayashi, K. Inoue, H. Sasaki, Y. Muragaki, and A. Ooshima. 1988. Collagen production in fat-storing cells after carbon tetrachloride intoxication in the rat: immunoelectron microscopic observation of type I, type III collagens, and prolyl hydroxylase. Lab. Invest. 59:509-521.

32. Ramadori, G., T. Veit, S. Schwogler, H. P. Dienes, T. Knittel, H. Rieder, and K.-H. Meyer zum Buschenfelde. 1990. Expression of the gene of the alphasmooth muscle-actin isoform in rat liver and in rat fat-storing (ITO) cells. Virchows Arch. B Cell Pathol. 59:349-357.

33. Chojkier, M., K. Houglum, J. Solis-Herruzo, and D. A. Brenner. 1989. Stimulation of collagen gene expression by ascorbic acid in cultured human fibroblasts. A role for lipid peroxidation? J. Biol. Chem. 264:16957-16962.

34. Pollock, S., and T. Campana. 1981. Immature red blood cells have ferritin receptors. Biochem. Biophys. Res. Commun. 100:1667-1672.
35. Moss, D., L. W. Powell, P. Arosio, and J. W. Halliday. 1991. Characterization of the ferritin receptors of human T lymphoid (MOLT-4) cells. J. Lab. Clin. Med. 119:273-279.

36. Baker, E., and E. H. Morgan. 1994. Iron transport. In Iron Metabolism in Health and Disease. J. H. Brock, J. W. Halliday, M. J. Pippard, and L. W. Powell, editors. W. B. Saunders Co., London. 63-95.

37. Ono, T., and S. Seno. 1990. Transport of ferritin from Kupffer cells to liver parenchymal cells. Int. J. Hematol. 54:93-102.

38. Carthew, P., R. E. Edwards, A. G. Smith, B. Dorman, and J. E. Francis. 1991. Rapid induction of hepatic fibrosis in the gerbil after the parenteral administration of iron-dextran complex. Hepatology. 13:534-539.

39. Cazzola, M., G. Bergamaschi, L. Dezza, and P. Arosio. 1990. Manipulations of cellular iron metabolism for modulating normal and malignant cell proliferation: achievements and prospects. Blood. 75:1903-1919.

40. Broxmeyer, H. E., L. Lu, D. C. Bicknell, D. E. Williams, S. Cooper, S. Levi, J. Salfeld, and P. Arosio. 1986. The influence of purified recombinant heavysubunit and light-subunit ferritins on colony formation in vitro by granulocytemacrophage and erythroid progenitor cells. Blood. 68:1257-1263.

41. Dezza, L., M. Cazzola, W. Piacibello, P. Arosio, S. Levi, and M. Aglietta. 1986. Effect of acidic and basic isoferritins on in vitro growth of human granulocyte-monocyte progenitors. Blood. 67:789-795.

42. Williams, D. E., S. Cooper, and H. E. Broxmeyer. 1988. The effect of hemopoietic suppressor molecules on the in vitro proliferation of murine granulocyte-macrophage progenitor cells (CFU-GM). Cancer Res. 48:1548-1550.

43. Fargion, S., M. D. Cappellini, A. L. Fracanzani, T. M. De Feo, S. Levi, P. Arosio, and G. Fiorelli. 1992. Binding and suppressive activity of human recombinant ferritins on erythroid cells. Am. J. Hematol. 39:264-268.

44. Broxmeyer, H. E. 1992. H-ferritin: a regulatory cytokine that down-modulates cell proliferation. J. Lab. Clin. Med. 120:367-370.

45. Bomford, A., C. Conlon-Hollingshead, and H. N. Munro. 1981. Adaptive responses of rat tissue isoferritins to iron administration: changes in subunit synthesis, isoferritin abundance, and capacity for iron storage. J. Biol. Chem. 256:948-955.

46. Kohgo, Y., M. Yokota, and J. W. Drysdale. 1980. Differential turnover of rat liver isoferritins. J. Biol. Chem. 255:5195-5200.

47. Arosio, P., T. G. Adelman, and J. W. Drysdale. 1978. On ferritin heterogeneity: further evidence for heteropolymers. J. Biol. Chem. 253:4451-4458.

48. Stefanini, S., E. Chiancone, P. Arosio, A. Finazzi-Agro, and E. Antonini. 1982. Structural heterogeneity and subunit composition of horse ferritins. Biochemistry. 21:2293-2299. 